\title{
The Governance of Digital Town Initiatives
}

\subsection{INTRODUCTION}

Urbanisation, globalisation, ageing populations, climate change, and technological breakthroughs pose inter-connected challenges to rural areas (OECD, 2019). Yet, as was evident during the COVID-19 pandemic, technological innovation offers new potentials for where people will live, and how, where and when they will work (OECD, 2019; McKinsey, 2020 ). With the right digital infrastructure, smaller towns and rural communities may offer workers and families a quality of life unavailable in metropolitan areas. At the same time, as the $\operatorname{OECD}(2019$, p. 16) notes "[...] without the right incentives and policy interventions, rural areas could miss out the benefits of the ongoing technological revolution further widening inequalities."

This chapter continues the discussion of enabling conditions for digital towns with a specific focus on the governance of digital town initiatives. This book assumes that the adoption and use of digital technologies is an essential component of town resilience, growth, and competitiveness in the Digital Society. This implies that towns need to integrate a digital layer, comprising technology and non-technology actors, into their existing physical, economic and social ecosystems. Realising the potentials related to digital initiatives within towns partly depends on the effectiveness of networks of informal and formal relationships and formal 
coordination structures that underpin efforts towards increasing and embedding digital initiatives. The remainder of this chapter discusses key concepts and terms in relation to building community resilience and specifically the nature and need for vertical and horizontal integration.

\subsection{Agenda Setting and Governance of Digital TOWN INITIATIVES}

The role of political and administrative leaders in regional and local planning includes agenda setting, co-ordinating, and influencing the actions of others (Clark, 2015). However, a simple focus on setting policy objectives and goals is insufficient in tackling complex and multifaceted objectives. Complex policy issues such as the environment, require horizontal and vertical policy coordination or integration because in such contexts governance and policy making is frequently characterised by "landscapes of functionally and/or spatially interdependent but fragmented arenas" (Hogl \& Nordbeck, 2012, p. 111). In some instances, as suggested by Torfing and colleagues (2012), some policy issues can now only be addressed by multiple stakeholders and where government organisations and conventional policy actors are no longer the dominant stakeholder.

The promise of digital town initiatives are multifaceted, including improved economic growth, population growth, better quality of life and, in the context of local governance, potential increased engagement in digital town initiatives and more open town governance (Meijer \& Rodríguez Bolívar, 2016). However, notwithstanding the multiplicity of initiatives that might be characterised as elements of "digital town plans", and the spectrum of activity from local community initiatives, to towndriven, to "stakeholder/town", to more state and national government initiatives, these is relative scarcity of work which evaluates programme outcomes in systematic ways (Hauge \& Prieger, 2010). This failure to systematically evaluate programmes and policies characterises many aspects of local and national policy.

The experience of existing digital town initiatives (Ashmore et al., 2015) suggest that digital towns require a broad concept of community governance that involves multi-agency working and self-organising networks that cut across organisational and stakeholder boundaries (Leach \& Percy-Smith, 2001). While digital technologies can lead to better town governance, as described in Chap. 3 , the focus here is on achieving better digital outcomes for the town rather than increased digital governance. 
This is a distinction between the content of governance, for example, in this context outcomes such as increased digitalisation, and the process of governance, for example, in this context increased civic engagement of citizens and stakeholder in the development of digital town plans and initiatives (Meijer \& Rodríguez Bolívar, 2016). Digital technologies can aid in increasing stakeholder involvement in digital initiatives, and improved digital public services is just one outcome that is an indicator of the Digital Town.

Policy objectives such as digitalisation and digital town initiatives require town and city officials to influence and shape policies, programmes, and processes which they do not directly control. In its broadest sense, this challenge of policy integration "concerns the management of crosscutting issues in policy-making that transcend the boundaries of established policy fields, which often do not correspond to the institutional responsibilities of individual departments" (Meijers \& Stead, 2004, p. 1).

Delivery on complex and multifaceted policy objectives such as town digitalisation can be considered from the perspective of town governance as an organisational or managerial challenge of how to organise and coordinate across a diverse range of stakeholders, including town governance structures (Torfing et al., 2012). Local governance structures may have advantages over more centralised state initiatives aimed at increasing digitalisation. For example, initiatives led by local governance structures with local stakeholder engagement may have better local contextual knowledge and better capacity to increase participation in initiatives (Hauge \& Prieger, 2010). However, local initiatives may suffer from insufficient resources, multiple, nested and conflicting goals, and less capacity to review outcomes of initiatives.

Policy governance involves effective institutional arrangements and coordination arrangements that are efficient and enable interaction and synchronisation. Interactive governance is "the complex process through which a plurality of actors with diverging interests interact in order to formulate, promote and achieve common objectives by means of mobilising, exchanging and deploying a range of ideas, rules and resources" (Torfing et al., 2012, p. 14). While new forms of governance can take different forms, a key feature of these newer forms of governance are that they pursue a common agreed objective, even though this may differ from the preferences of individual stakeholders. Furthermore, in these more complex and process orientated forms of governance, the focus is on inducing actors to engage in multi-actor actions, without one person or organisations in control (Torfing et al., 2012). 
The changes involved in moving towards a digital town may reflect a process of incremental changes in town governance or in some instances it could involve more fundamental and transformative changes to governance structure (Meijer \& Rodríguez Bolívar, 2016). Notwithstanding the case for new forms of governance, there are strong arguments that in many multi-level systems of governance the reality is that at least the key decisions remain within centralised structures (Marshall, 2008) or alternatively the multi-levels separate, losing the elements of integration across actors (Young, 2006).

\subsection{Community Resilience, Vertical Integration, AND HorizonTAL INTEGRATION}

Resilience, borrowing from the sciences, refers to the capacity to bounce back to an equilibrium after a disturbance or adversity (Norris et al., 2008 ). It has been applied in a variety of regional contexts including individuals, sectoral, local knowledge production, local entrepreneurship, and community resilience after a sudden shock, crisis or disaster (Gong \& Hassink, 2017). Historically, the study of community resilience focussed on the ability of communities to withstand disturbances and (re-)organise to maintain their social infrastructures (Adger, 2000). More recently, a wider view of community resilience, couched in socio-ecological systems, recognises that community resilience does not only include sustenance, recovery, and renewal, but varying degrees of transformation (Magis, 2010; Gong \& Hassink, 2017). In this way, community resilience includes adaptation to or in anticipation of future or slowly developing changes, so-called slow burns (Gong \& Hassink, 2017).

Norris et al. (2008) suggest that community resilience emerges from four primary sets of adaptive capacities:

- Economic development - the degree of resource volume and diversity, and resource equity and social inclusion within a community;

- Social capital-the strength of network structures and linkages, social support, and community bonds, roots, and commitments within a community;

- Information and communication-the systems and infrastructure for informing the Public, and the presence of communal narratives that give the experience shared meaning and purpose; and 
- Community competence-the ability of the community to participate in collective action and decision making with collective efficacy and empowerment.

Research suggests that local communities and community capital play an important role in building community resilience (Berkes \& Ross, 2013; McDonnell et al., 2019). In this sense, it is the very substance of a community that builds resilience. As Berkes and Ross (2013, p. 14) put it, community resilience is "[...] a function of the strengths or characteristics that have been identified as important, leading to agency and selforganisation." These characteristics include people-place relationships, a diverse and innovative economy, community infrastructure, positive outlook, values and beliefs, social networks, knowledge skills and learning, leadership, and not least, engaged governance (Berkes \& Ross, 2013). Indeed, agency and self-organisation are, in many respects, the essence of community resilience. This is consistent with the view of the OECD discussed in Chap. 4 who believe that rural areas should drive their own economic development rather than rely on national government, specifically with respect to identifying and mobilising assets to improve economic performance (OECD, 2014).

Building community resilience does not take place in isolation. Indeed, the act of empowerment infers coordination with a higher administrative authority and community implies coordination across multiple actors. As such, in the context of the participatory policy making and policy implementation discussed above, both vertical and horizontal integration are key. Horizontal and vertical integration, terms borrowed from Warren (1963), were used by Berke et al. (1993) to classify communities based on the strength of their interactions between local and national players and in terms of the degree of coherence. Vertical integration of policy making refers to the integration across different levels within the governance or policy sphere. Vertical integration is important as it may provide access to resources and it may facilitate the influencing of policy and programmes. For example, McDonnell et al. (2019) suggests that by adapting policies to local needs, communities can access resources, gain effective power and influence, and communicate better with external actors. Even though in a disaster planning context, McDonnell et al. (2016) offers some guidance on defining and characterising horizontal and vertical integration (Table 8.1).

Horizontal integration refers to integration across different elements of policy making, and across policy and other stakeholders, typically those 
Table 8.1 Definitions and selected characteristics of horizontal and vertical integration (adapted from McDonnell et al., 2016)

\begin{tabular}{|c|c|c|}
\hline Dimension & Definition & Characteristics \\
\hline $\begin{array}{l}\text { Horizontal } \\
\text { integration }\end{array}$ & $\begin{array}{l}\text { - Inter-relations among } \\
\text { members of local communities } \\
\text { in terms of social ties, } \\
\text { collective action, and } \\
\text { responsibility; neighbourhood } \\
\text { ownership and sense of place; } \\
\text { resource mobilisation; and } \\
\text { awareness of disaster } \\
\text { vulnerabilities and community } \\
\text { assets } \\
\text { Relations between local } \\
\text { citizens and organisations, } \\
\text { including emergency services, } \\
\text { schools, churches, non- } \\
\text { governmental and nonprofit } \\
\text { organisations, associations, } \\
\text { boards of business, Chambers } \\
\text { of Commerce, and } \\
\text { community groups. }\end{array}$ & $\begin{array}{l}\text { Institutional mandates incl. } \\
\text { Positions accessible to citizens, } \\
\text { formal outreach plan, publicised } \\
\text { meetings, and regular progress } \\
\text { reports. } \\
\text { Representation and scope incl. } \\
\text { Local participation in committee } \\
\text { formation and membership } \\
\text { criteria. } \\
\text { Role of technical expertise in } \\
\text { encouraging participation incl. } \\
\text { Facilitation of public engagement } \\
\text { and reflection of public opinion. } \\
\text { Contribution of the final output } \\
\text { (plan) to participation incl. } \\
\text { commitment to public engagement } \\
\text { and local capacity building. } \\
\text { Alignment of professional expertise } \\
\text { and local needs. }\end{array}$ \\
\hline $\begin{array}{l}\text { Vertical } \\
\text { integration }\end{array}$ & $\begin{array}{l}\text { Connection and access to } \\
\text { political, social, and economic } \\
\text { institutions and agencies, } \\
\text { which may facilitate the flow } \\
\text { of resources and adjusting } \\
\text { policies in response to } \\
\text { disasters and in anticipation of } \\
\text { possible future risks. }\end{array}$ & $\begin{array}{l}\text { - State (Regional) leadership. } \\
\text { Encouraging stronger vertical ties } \\
\text { by Program Design. } \\
\text { - Facilitating upward flow of } \\
\text { information incl. Independent } \\
\text { organization and mandated/ } \\
\text { required upward flow. } \\
\text { Engendering active citizen } \\
\text { influence incl. local participation in } \\
\text { risk identification, public input } \\
\text { prior to final projects, and project } \\
\text { evaluation. }\end{array}$ \\
\hline
\end{tabular}

considered at the same level of governance but with different responsibilities and objectives. It is concerned with organising and coordinating the policy fields in a specific area and normally refers to all the actors operating at that level, even if some of them may be the delivery function of a national (or regional) ministry. It involves both "(a) inter-relations among members of local communities in terms of social ties, collective action and responsibility, neighbourhood ownership and sense of place, resource 
mobilization, and awareness of disaster vulnerabilities and community assets; and (b) relations between local citizens and organizations [...]" (McDonnell et al., 2019, p. 313). By its nature, horizontal integration is difficult to 'organise' as it requires much greater flexibility in developing and changing objectives, ways of organising and engagement with stakeholders. The EU URBACT project suggests that this coordination will involve looking for solutions at a level above or below the level where the problem manifests-so seeking support from state or national government, or seeking solutions by engaging with local stakeholders, or perhaps combining multiple levels simultaneously (Clark, 2015).

In the context of digital town initiatives, while vertical integration is important, we suggest greater emphasis should be placed on horizontal integration. Firstly, focusing solely on supply-side interventions (e.g., the roll out of broadband services) does not address the demand-side barriers to use of digital services. Horizontal integration allows for both supplyside and demand-side issues to be addressed. Similarly, emphasising broader bottom-up participation may overcome the disadvantages associated with a predominately top-down model of planning (Putnam et al., 2004) which may fail to capture local knowledge, local needs, and local social capital. Notwithstanding this, digital initiatives that build on the problems/challenges/needs of local citizens, businesses and organisations are more likely to become embedded where there is integration across policy makers. Involving users early in the design processes increases the likelihood of success for initiatives. Stakeholders may need to develop physical infrastructure, as well as supporting digital solutions, and therefore will need to engage across a number of stakeholders including government agencies and state-owned companies. In this respect, online town portals and platforms have been cited as key components in digital town projects (da Rocha, 2002; Hervé-Van Driessche, 2001).

Research on the capacity for communities to engage in collective action suggests that communities face difficulties in organising for collective action if the capacity for horizontal integration is missing or low (McDonnell et al., 2019). To deliver on broad goals such as a digital town agenda requires governance structures that recognise the role of local agency in strengthening the capacity across stakeholders to tackle and deliver on digital initiatives, rather than the centralisation of capacity and resources into an existing central governance system (Landry, 2006). In particular, smaller towns may lack the decision-making power and revenue generating capacity to support a digital town initiative, thus requiring strong levels of vertical integration for success. McDonnell et al. (2019) 
further suggest that communities characterised by a low capacity for vertical integration will be slower to engage with central authorities. Even where such capacity exists, towns may face resistance to change in governance structures. The governance of digital town initiatives is dependent on not just incremental changes within existing governance structures, but also requires engagements with a broader range of stakeholders, from external policy and government bodies as well as local stakeholders, that result in new forms of governance of projects and initiatives. Successful engagement with a wide range of stakeholder groups can suffer from miscommunication, exclusion of salient voices, and paralytic stalemates (Torfing et al., 2012). Likewise, participation by local stakeholders may not result in representative participation of stakeholders as, frequently, groups and individuals with specific interests will dominate the participation process. For example, it has been shown that higher levels of income and education is associated with participation (Weber, 2000) and participation is driven by those with personal or business interests and those who have the resources and time to commit to regular participation (Irvin \& Stansbury, 2004). Finally, a significant critique of local digital town plans and bottom-up initiatives is that the capacity to evaluate the effectiveness of actions and interventions may be missing at a local town level (Hauge \& Prieger, 2010). LaRose et al. (2011) found that local community efforts to publicise and demonstrate broadband applications increased adoption, though they did not find strong evidence that local broadband availability produced greater community satisfaction or local individual economic development activities.

\subsection{Measuring the Governance of Digital TOWN INITIATIVES}

Given that the overwhelming majority of frameworks and composite indices for the digital society and digital economy are national frameworks, few assess the specific governance of ICT initiatives. Even where governance is measured, it is in a context largely irrelevant to smaller and rural towns. In contrast, both the IMD-SUTD Smart City Index and the CityKeys project, include governance specific indicators. IMD-SUTD (Bris et al., 2019) include four specific governance indicators:

- Information on local government decisions are easily accessible;

- Corruption of city officials is not an issue of concern; 
- Residents contribute to decision making of local government; and

- Residents provide feedback on local government projects.

Firstly, the IMD-SUTD framework is demand-side only and other than individual residents provides very little information that can be used to measure vertical or horizontal integration.

The CityKeys framework goes further with three sub-dimensions to measure governance-organisation, community involvement (Bosch et al., 2017). Unlike the IMD-SUTD framework, CityKeys includes indicators that might act as proxies for vertical and horizontal integration (Table 8.2), however not to the extent presented by McDonnell et al. (2016) in Table 8.1.

It is worth noting that the availability on an online town portal or platform is not included in extant frameworks. Furthermore, the concept of community resilience is not reflected in these measurement frameworks. In the context of digital towns, one might reasonably ask "resilience to what?" The answer to which might be the changes being brought to society and economies due to ongoing digital technology evolution. While frameworks do exist for measuring resilience to disasters (Jordan \& Javernick-Will, 2012; Clark-Ginsberg et al., 2020), economic resilience (Dinh \& Pearson, 2015), and both social and economic community resilience (Sherrieb et al., 2010), there would seem to be a dearth of validated

Table 8.2 CityKeys governance dimensions and indicators (Bosch et al., 2017)

\begin{tabular}{|c|c|}
\hline Dimension & Indicator title \\
\hline \multirow{4}{*}{ Organisation } & Cross-departmental integration. \\
\hline & $\begin{array}{l}\text { Establishment of leadership and resources within the } \\
\text { administration. }\end{array}$ \\
\hline & $\begin{array}{l}\text { Monitoring and evaluation of compliance with smart city } \\
\text { requirements. }\end{array}$ \\
\hline & Availability of government data. \\
\hline Community & Citizen participation in projects. \\
\hline \multirow[t]{2}{*}{ involvement } & Open public participation. \\
\hline & Voter participation in municipal elections. \\
\hline \multirow[t]{3}{*}{ Multi-level governance } & Strategies and Policies: Smart city policy. \\
\hline & $\begin{array}{l}\text { Budget: Expenditures by the municipality for a transition } \\
\text { towards a smart city. }\end{array}$ \\
\hline & $\begin{array}{l}\text { The extent to which the city cooperates with other authorities } \\
\text { from different levels. }\end{array}$ \\
\hline
\end{tabular}


measurement frameworks for community digital resilience (Nguyen \& Akerkar, 2020). This lack of measurement frameworks may be explained by a combination of the nascency of both the digital town literature and the non-disaster community resilience literature, but also the relative complexity in translating digital town governance, including vertical and horizontal integration and the adaptive capacities proposed by Norris et al. (2008), into measurable indicators.

\subsection{Conclusions}

Putting in place the community governance structures to adapt for technological change in society and the economy is a complex task, even for a smaller or rural town. It requires a multi-stakeholder approach to coordinating and reconfiguring resources at local, regional and national levels. To build resilience to digital technology evolution requires mechanisms that can enable a town, its structures, institutions and stakeholders to keep pace with this change. This may require or catalyse new forms of community governance, agency and self-governance and increased coordination both within towns and with external actors, each of which may have different, potentially conflicting, objectives for pursuing increased digitalisation within the town.

\section{REFERENCES}

Adger, W. N. (2000). Social and ecological resilience: Are they related? Progress in Human Geography, 24(3), 347-364.

Ashmore, F. H., Farrington, J. H., \& Skerratt, S. (2015). Superfast broadband and rural community resilience: Examining the rural need for speed. Scottish Geographical Journal, 131(3-4), 265-278.

Berke, P. R., Kartez, J., \& Wenger, D. (1993). Recovery after disaster: Achieving sustainable development, mitigation and equity. Disasters, 17(2), 93-109.

Berkes, F., \& Ross, H. (2013). Community resilience: Toward an integrated approach. Society \& Natural Resources, 26(1), 5-20.

Bosch, P., Jongeneel, S., Rovers, V., Neumann, H. M., Airaksinen, M., \& Huovila, A. (2017). CITYkeys indicators for smart city projects and smart cities. CITYkeys report.

Bris, A., Chee, C. H., \& Lanvin, B. (2019). Smart City Index. The IMD World Competitiveness Center, Singapore, Singapore.

Clark, G. (2015). OPENCities Thematic Paper 1. Leadership \& Governance of OPENCities (summary). https://urbact.eu/sites/default/files/import/ Projects/Open_Cities/outputs_media/Paper__Leadership__Governance.pdf 
Clark-Ginsberg, A., McCaul, B., Bremaud, I., Cáceres, G., Mpanje, D., Patel, S., \& Patel, R. (2020). Practitioner approaches to measuring community resilience: The analysis of the resilience of communities to disasters toolkit. International Journal of Disaster Risk Reduction, 50, 101714.

da Rocha, N. P. (2002). Aveiro-Digital town. In Advances in digital government (pp. 305-314). Springer.

Dinh, H., \& Pearson, L. (2015). Specifying community economic resilience-A framework for measurement. Australasian Journal of Regional Studies, $21(3), 278-302$.

Gong, H., \& Hassink, R. (2017). Regional resilience: The critique revisited. In Creating resilient economies. Edward Elgar Publishing.

Hauge, J. A., \& Prieger, J. E. (2010). Demand-side programs to stimulate adoption of broadband: What works? Available at SSRN 1492342.

Hervé-Van Driessche, K. (2001). Parthenay, the digital town: Myth or reality? Telematics and Informatics, 18(1), 5-15.

Hogl, K., \& Nordbeck, R. (2012). The challenge of coordination: Bridging horizontal and vertical boundaries. In Environmental governance. Edward Elgar Publishing.

Irvin, R. A., \& Stansbury, J. (2004). Citizen participation in decision making: Is it worth the effort? Public Administration Review, 64(1), 55-65.

Jordan, E., \& Javernick-Will, A. (2012). Measuring community resilience and recovery: A content analysis of indicators. In Construction Research Congress 2012: Construction Challenges in a Flat World (pp. 2190-2199).

Landry, C. (2006). The art of city-making. Routledge.

LaRose, R., Strover, S., Gregg, J. L., \& Straubhaar, J. (2011). The impact of rural broadband development: Lessons from a natural field experiment. Government Information Quarterly, 28(1), 91-100.

Leach, R., \& Percy-Smith, J. (2001). Local governance in Britain. Palgrave.

Magis, K. (2010). Community resilience: An indicator of social sustainability. Society and Natural Resources, 23(5), 401-416.

Marshall, G. R. (2008). Nesting, subsidiarity, and community-based environmental governance beyond the local level. International Journal of the Commons, 2(1), 75-97.

McDonnell, S., Desai, S., Berkovits, D., Ghorbani, P., \& Jessa, M. (2016). A managed-participatory approach to community resiliency. The Nelson A. Rockefeller Institute for Government.

McDonnell, S., Ghorbani, P., Wolf, C., Cruz, M. J., Burgy, D. M., Desai, S., Berkovits, D., \& Silberblatt, R. (2019). A managed-participatory approach to community resilience: The case of the New York Rising Community Reconstruction program. The American Review of Public Administration, $49(3), 309-324$. 
McKinsey. (2020). How COVID-19 has pushed companies over the technology tipping point-And transformed business forever. https://www.mckinsey. com/business-functions/strategy-and-corporate-finance/our-insights / how-covid-19-has-pushed-companies-over-the-technology-tipping-point-andtransformed-business-forever

Meijer, A., \& Rodríguez Bolívar, M. P. (2016). Governing the smart city: A review of the literature on smart urban governance. International Review of Administrative Sciences, 82(2), 392-408.

Meijers, E., \& Stead, D. (2004). Policy integration: What does it mean and how can it be achieved? A multi-disciplinary review. In Berlin Conference on the Human Dimensions of Global Environmental Change: Greening of PoliciesInterlinkages and Policy Integration, Berlin.

Nguyen, H. L., \& Akerkar, R. (2020). Modelling, measuring, and visualising community resilience: A systematic review. Sustainability, 12(19), 7896.

Norris, F. H., Stevens, S. P., Pfefferbaum, B., Wyche, K. F., \& Pfefferbaum, R. L. (2008). Community resilience as a metaphor, theory, set of capacities, and strategy for disaster readiness. American Journal of Community Psychology, 41(1), 127-150.

OECD. (2014). Innovation and modernising the rural economy. https://read. oecd-ilibrary.org/urban-rural-and-regional-development/innovation-andmodernising-the-rural-economy_9789264205390-en\#pagel

OECD. (2019). Rural 3.0: People centred rural policy-Policy highlights. https://www.oecd.org/rural/rural-development-conference/documents / Rural-3.0-Policy-Highlights.pdf

Putnam, R. D., Feldstein, L., \& Cohen, D. J. (2004). Better together: Restoring the American community. Simon and Schuster.

Sherrieb, K., Norris, F. H., \& Galea, S. (2010). Measuring capacities for community resilience. Social Indicators Research, 99(2), 227-247.

Torfing, J., Peters, B. G., Pierre, J., \& Sørensen, E. (2012). Interactive governance: Advancing the paradigm. Oxford University Press on Demand.

Warren, R. L. (1963). The community in America. No. HT123 W3.

Weber, E. P. (2000). A new vanguard for the environment: Grass-roots ecosystem management as a new environmental movement. Society \& Natural Resources, $13(3), 237-259$.

Young, O. (2006). Vertical interplay among scale-dependent environmental and resource regimes. Ecology and Society, 11(1), 27. 
Open Access This chapter is licensed under the terms of the Creative Commons Attribution 4.0 International License (http://creativecommons.org/licenses/ by $/ 4.0 /)$, which permits use, sharing, adaptation, distribution and reproduction in any medium or format, as long as you give appropriate credit to the original author(s) and the source, provide a link to the Creative Commons licence and indicate if changes were made.

The images or other third party material in this chapter are included in the chapter's Creative Commons licence, unless indicated otherwise in a credit line to the material. If material is not included in the chapter's Creative Commons licence and your intended use is not permitted by statutory regulation or exceeds the permitted use, you will need to obtain permission directly from the copyright holder. 